\section{Antitranspirant Application Increases Grafting Success of Watermelon}

\author{
Sahar Dabirian and Carol A. Miles ${ }^{1}$
}

ADDITIONAL INDEX WORDs. healing, survival, grafted watermelon, stomatal conductance, transpiration

SUMMARY. The one-cotyledon splice grafting method is commonly used for watermelon (Citrullus lanatus) because it is relatively rapid and there is less rootstock regrowth than with other grafting methods. However, plants must rely on moisture in the air for survival during at least the first 4 days after grafting. In 2015 and 2016, greenhouse experiments were conducted to investigate if application of commercial stomata-coating and stomata-closing antitranspirant products, applied 1 day before grafting to both scion and rootstock seedlings, could increase the survival of watermelon transplants grafted using the one-cotyledon method.

'TriX Palomar' watermelon was grafted onto rootstock 'Tetsukabuto' (Cucurbita maxima $\times$ C. moschata) in Expt. 1, and onto rootstock 'Emphasis' (Lagenaria siceraria) in Expt. 2. The survival of grafted watermelon differed because of experiment $(P=0.0003)$, antitranspirant treatment $(P<0.0001)$, and experimental repeat $(P<0.0001)$. The survival of 'TriX Palomar' grafted onto 'Tetsukabuto' was greatest for plants treated with the stomata-coating + stomata-closing antitranspirants $(92 \%$ to $100 \%)$, followed by the stomata-closing antitranspirant $(79 \%$ to $97 \%)$, water $(72 \%)$, and the stomata-coating antitranspirant (50\% to $60 \%)$. For 'TriX Palomar' grafted onto 'Emphasis', plants treated with the stomata-closing antitranspirant had the greatest survival (87\% to $97 \%)$, followed by stomata-coating + stomata-closing antitranspirants (84\% to $94 \%)$, the stomata-coating antitranspirant (50\% to 67\%), and water (53\% to 68\%). In Expt. 3, stomatal conductance (gs) was similar for both 'TriX Palomar' and 'Emphasis' seedlings before treatment application, but differed because of the treatments 1 and 2 days after application. Stomatal conductance did not change for 'TriX Palomar' seedlings after application of the stomata-coating antitranspirant or water, or for 'Emphasis' seedlings after application of the stomata-coating antitranspirant. Stomatal conductance of 'TriX Palomar' seedlings decreased $57 \%$ to $62 \%$ after application of the stomata-closing antitranspirant and decreased $48 \%$ to $60 \%$ after application of the stomata-coating + stomata-closing antitranspirants. Stomatal conductance for 'Emphasis' seedlings increased $37 \%$ after water application, and decreased $58 \%$ to $68 \%$ after application of the stomata-closing antitranspirant, and decreased $42 \%$ to $45 \%$ after application of the stomata-coating + stomata-closing antitranspirants. The survival rate of grafted 'TriX Palomar' transplants was increased nearly $30 \%$ by application 1 day before grafting of the commercial stomata-closing antitranspirant or stomatacoating + stomata-closing antitranspirants in this study. Increase in grafting success is likely due to a reduction in transpiration that occurs when the stomataclosing antitranspirant is applied to the seedlings before grafting.

G rafting cucurbitaceous crops is an important integrated pest management strategy used to control several soilborne pathogens and nematodes (Buller et al., 2013; Cohen et al., 2007; Davis

Department of Horticulture, Washington State University, Northwestern Washington Research and Extension Center, Mount Vernon, WA 98273.

Technical assistance provided by Patricia Kreider, Edward Scheenstra, and Todd Coffey, and funding support provided by the Washington State Department of Agriculture SCBG No. K1506, USDA-NIFA SCRI No. 2011-51181-30963, Northwest Agricultural Research Foundation, Washington State Commission for Pesticide Registration, and State project WN00375-Acc. No. 1008680, are gratefully acknowledged.

${ }^{1}$ Corresponding author. E-mail: milesc@wsu.edu.

doi: 10.21273/HORTTECH03739-17 et al., 2008; Guan et al., 2012; Louws et al., 2010). Although grafting holds promise as a disease management strategy for watermelon production in Washington (Buller et al., 2013; Dabirian et al., 2017; Wimer et al., 2015), adoption is limited due in part to the cost of grafted transplants.
Increased production costs related to grafting include extra seed and greenhouse facilities needed to grow rootstock seedlings, skilled labor needed for grafting, and special facilities required for successful healing of the grafted plants (Boughalleb et al., 2007; Galinato et al., 2016; Lewis et al., 2014; Rivard et al., 2010). The cost of grafted transplants increases if grafting survival rates are low. Although large-scale grafting operations use controlled environment facilities that lead to greater grafting success, smaller grafting operations use healing chambers where environmental conditions are less controlled.

When the healing chamber environmental conditions are variable, survival of grafted watermelon tends to be lower and less reliable than for other grafted vegetable crops, and grafted watermelon tends to require greater care. In a study using a low cost healing chamber, survival of grafted tomato (Solanum lycopersicum) was $98 \%$, whereas the survival of grafted watermelon ranged from $51 \%$ to $80 \%$ (Johnson and Miles, 2011 ; C.A. Miles, unpublished data). The survival of grafted watermelon is lower in general than for other commonly grafted vegetable crops because of the particular grafting technique used (one-cotyledon splice) as well as the susceptibility of the plant to desiccation after the grafting procedure. Desiccation of grafted seedlings occurs because of water stress to the scion during healing and hardening after grafting (Shirai and Hagimori, 2004). During the grafting process, the xylem is severed and the scion is under extreme water stress until xylem tissues of the scion and rootstock heal. Water stress manifests itself in plants as wilting, turgidity loss, and drying (Atkinson and Else, 2001). When water absorption by roots is suppressed at the graft union (because water cannot pass from the rootstock to the scion

\begin{tabular}{llll}
\hline $\begin{array}{l}\text { Units } \\
\text { To convert U.S. to SI, } \\
\text { multiply by }\end{array}$ & U.S. unit & SI unit & $\begin{array}{l}\text { To convert SI to U.S., } \\
\text { multiply by }\end{array}$ \\
\hline 10.7639 & $\mathrm{fc}$ & lux & 0.0929 \\
29.5735 & $\mathrm{fl} \mathrm{oz}$ & $\mathrm{mL}$ & 0.0338 \\
0.3048 & $\mathrm{ft}$ & $\mathrm{m}$ & 3.2808 \\
2.54 & inch $(\mathrm{es})$ & $\mathrm{cm}$ & 0.3937 \\
25.4 & inch $(\mathrm{es})$ & $\mathrm{mm}$ & 0.0394 \\
0.0254 & mil & $\mathrm{mm}$ & 39.3701 \\
$\left({ }^{\circ} \mathrm{F}-32\right) \div 1.8$ & ${ }^{\circ} \mathrm{F}$ & ${ }^{\circ} \mathrm{C}$ & $\left({ }^{\circ} \mathrm{C} \times 1.8\right)+32$
\end{tabular}


while the graft union is not yet healed), $g_{s}$ and scion growth decreases (Oda et al., 2005). To minimize water stress, it is necessary to reduce transpiration for several days immediately after grafting (Rivard and Louws, 2006).

Normally, plants react to water deficit with rapid, abscisic acid (ABA)mediated closure of stomata, which results in reduced transpiration (Leung and Giraudat, 1998; Pospisilova, 2003; Willmer and Pricker, 1996). Manipulating the ABA signaling pathway may reduce water consumption by plants, thereby reducing transpiration under stress conditions (Gomez-Cadenas et al., 2003; Grill and Ziegler, 1998). When roots become stressed because of water deficit, ABA concentration rises in xylem vessels and is transported to leaves by transpiration streaming (Davies and Zhang, 1991; Khalil and Grace, 1993; Zhang and Davies, 1990). ABA controls transpiration by regulating the opening of stomata (Hetherington and Davis, 1998). Lee et al. (2005) demonstrated that $\mathrm{ABA}$ functions in roots to allow better uptake of water by affecting conformation of water channels in root cell membranes and in the shoot.

There are commercial products available that reduce water stress, including both stomata-coating and stomata-closing compounds that increase resistance of leaves to water vapor loss (Tambussi and Bort, 2007). Under severe water stress, these products can increase stomatal resistance and mitigate water stress, thereby maintaining plant growth and development (Moftah and AlRedhaiman, 2006). Such antitranspirant products can be applied to foliage or the root zone to counteract water stress. Application of an antitranspirant promoted shoot growth and graft success in sweet pepper [Capsicum annuum (Nitzsche et al., 1991)]. Johkan et al. (2008) reported that stomatal closure increased in sweet pepper plants receiving an ascorbic acid treatment, and survival of grafted sweet pepper plants was improved because of increased water potential in plants. Foliar application of ascorbic acid $\mathrm{l} d$ after grafting increased stomatal resistance and water potential of older $(58 \mathrm{~d}$ old $)$ grafted sweet pepper plants to a level similar to that found in untreated younger (34 d old) plants (Johkan et al., 2009). Increased stomatal resistance led to stomatal closure, which decreased plant defoliation and increased survival of grafted scions. Decreases in transpiration due to stomatal closure is likely important for achieving successful grafting. The objective of the current study was to test whether the application of commercial antitranspirant products to rootstock and scion seedlings before grafting increases the survival of grafted watermelon transplants.

\section{Materials and methods}

Two experiments to test the effect of commercial antitranspirant products on grafting success for watermelon were carried out at the Washington State University Northwestern Washington Research and Extension Center (WSU NWREC) greenhouse facilities in Mount Vernon, WA. To understand if antitranspirant products affected $g_{S}$ of seedlings, a third experiment was conducted using nongrafted scion and rootstock seedlings.

Grafting success. Experiments 1 and 2 were carried out in the greenhouse in 2015 and 2016, respectively. Both experiments used a randomized complete block design with the same four treatments (see Antitranspirant Treatments). Experiment 1 had four replicates of the four treatments, with 18 plants per experimental unit, and was repeated two times. Seedless watermelon 'TriX Palomar' (Syngenta Seeds, Minneapolis, $\mathrm{MN}$ ) was sown into 72 -cell trays filled with potting mix (Sunshine \#3 N \& O; Sun Gro Horticulture, Agawam, MA) on 17 Jan. (repeat 1) and 24 Feb. (repeat 2) in 2015. Rootstock 'Tetsukabuto' (American Takii, Salinas, CA) was seeded in every other length-wise row in a 72-cell tray on 25 Jan. (repeat 1 ) and 3 Mar. (repeat $2)$. Grafting was carried out on 3 Feb. and 12 Mar. for repeats 1 and 2 , respectively.

Experiment 2 had five replicates of the four treatments, with 12 plants per experimental unit, and was also repeated two times. 'TriX Palomar' was sown into 72 -cell trays using the same potting mix as Expt. 1, on 11 Jan. (repeat 1) and 19 Jan. (repeat 2) in 2016. Rootstock 'Emphasis' (Syngenta Seeds) was seeded in every other length-wise row in 72-cell trays on 19 Jan. (repeat 1) and 27 Jan (repeat 2). Grafting was carried out on 29 Jan. and 5 Feb. for repeats 1 and 2 , respectively.

ANTITRANSPIrANT TREATMENTS. Both experiments included two commercial antitranspirant products; one was a stomata-coating antitranspirant (Moisturin; WellPlant, Sparks, $\mathrm{NV}$ ) and the other was a stomataclosing antitranspirant (Root-Zone, WellPlant). The stomata-coating antitranspirant was foliar applied to form a coating on the plant surface that is reputed to reduce water loss. The stomata-closing antitranspirant is a humectant formulation applied as a soil drench to the root system; this is reputed to condition the plant to produce additional amounts of $\mathrm{ABA}$, causing closure of stomata and reduction in transpiration rate. In both experiments, commercial products were applied according to label rate, and the four treatments were l) stomatacoating antitranspirant as a $10 \%$ solution, 2) stomata-closing antitranspirant as a $1.56 \%$ solution, 3 ) stomata-coating + stomata-closing antitranspirant (applied at the same rates as treatments 1 and 2, respectively), and 4) tap water (control). Treatments were applied 22-24 h before grafting, between 8:00 and 9:30 AM in both experiments, following label recommendations. The stomata-coating antitranspirant $(3 \mathrm{~mL})$ was applied to both sides of leaves of each scion and rootstock seedling, according to the label instructions. The stomataclosing antitranspirant $(30 \mathrm{~mL})$ was applied as a drench to each scion and rootstock seedling. For the water treatment, $30 \mathrm{~mL}$ of water was applied as a drench to each scion and rootstock seedling.

Grafting METHOD. The onecotyledon grafting method was used in both experiments. The rootstock seedling was cut at a $60{ }^{\circ} \mathrm{C}$ angle so that one cotyledon remained and one was removed from the seedling. The scion was cut at a $60{ }^{\circ} \mathrm{C}$ angle $\approx 2 \mathrm{~cm}$ below cotyledons. The two cut stem surfaces were placed together and a watermelon grafting clip $(3 \mathrm{~mm}$; Johnny's Selected Seeds, Fairfield, ME) held the grafted transplant together. Immediately after grafting, plants were placed in a healing chamber for $9 \mathrm{~d}$.

Healing chamber conditions AND PLANT SURVIVAL. The healing 
chamber was $3 \mathrm{ft}$ wide $\times 5.6 \mathrm{ft}$ long $\times$ $1.6 \mathrm{ft}$ tall on a bench in the greenhouse. The temperature and relative humidity $(\mathrm{RH})$ were measured inside the chamber and in the greenhouse during both experiments every 15 min (Hobo Onset, Bourne, MA); light was measured every 15 min only in Expt. 2 (equipment was not available earlier). For both experiments, each tray was placed in the healing chamber immediately after grafting, and the healing regimen described by Miles et al. (2016) was followed to transition plants to the greenhouse environment, and is summarized here. The chamber was covered with clear plastic (6-mil polythene; Ginegar Plastic Products, Ginegar, Israel) and a thin film of water was added to the chamber floor to achieve $100 \%$ $\mathrm{RH}$ inside the chamber. The chamber was covered with black fabric (Geotex 200ST; Propex Operating Co., Chattanooga, TN) to limit light penetration to plants during the first $6 \mathrm{~d}$ after grafting. For the day of grafting (day 1) and for $2 \mathrm{~d}$ after grafting (day 3 ), the chamber was entirely covered with plastic and black fabric. The chamber was opened on day 3 , and water was added to the chamber floor so that it was barely wet, then the chamber was closed. On day 4, the chamber was opened for $15 \mathrm{~min}$, and water was added to the floor of the chamber as needed so that it was barely wet, the chamber was closed, and the black fabric was folded up to expose the front side of the chamber. On day 5 , the chamber was opened for $30 \mathrm{~min}$, and water was added to the floor of the chamber as needed, the chamber was closed, and the black fabric was folded up to expose the sides of the chamber but the top of the chamber remained covered. On day 6 , the chamber was opened for $\mathrm{l} \mathrm{h}$, and water was added to the floor of the chamber as needed, the chamber was closed, and the black fabric was entirely removed. On days 7 and 8 , the chamber was opened for 3 and $6 \mathrm{~h}$, respectively; water was added to the floor of the chamber as needed, and the chamber was closed. Plants were removed from the chamber on day 9 and placed on the greenhouse bench and watered. Survival was assessed for the grafted plants in each replicate treatment at $7,10,14$, and $21 \mathrm{~d}$ after grafting. Graft survival was defined as turgidity of scion leaves and stem; failed grafted plants had entirely wilted scion leaves and stems. Stomatal conductance. In Expt. 3, gs of seedlings of 'TriX Palomar' watermelon and 'Emphasis' rootstock were measured with a leaf porometer (SC-1; Decagon Devices, Pullman, WA) $1 \mathrm{~h}$ before application of the antitranspirants (day 0 ) and $1 \mathrm{~d}$ and $2 \mathrm{~d}$ after application. Experiment 3 was carried out at the same time as repeat 2 of Expt. 2, and included the same planting dates ('TriX Palomar' seeded on 19 Jan. 2016 and 'Emphasis' seeded on 27 Jan. 2016) and production methods, as well as the same four treatments; at day 1 , seedlings were the correct size for grafting. Experiment 3 included four replicates each of three 'TriX Palomar' seedlings and five 'Emphasis' seedlings; however, the experiment was not repeated. Stomatal conductance was measured between 11:30 AM and 1:30 PM on 4, 5, and 6 Feb. (days 0,1 , and 2, respectively) (Pietragalla and Pask, 2012). To account for the effect of time of day on $g_{s}$, one plant in each treatment was measured sequentially. Measurements were completed for 'TriX Palomar' seedlings and then for 'Emphasis'

Table 1. Survival of 'TriX Palomar' watermelon grafted onto 'Tetsukabuto' rootstock treated $1 \mathrm{~d}$ before grafting with a stomata-closing antitranspirant, a stomata-coating antitranspirant, stomata-coating + stomata-closing antitranspirants, or water; survival was measured at $7,10,14$, and $21 \mathrm{~d}$ after grafting, which was 3 Feb. 2015 (repeat 1) and 12 Mar. 2015 (repeat 2) at Mount Vernon, WA.

\begin{tabular}{lcccc}
\hline & \multicolumn{4}{c}{ Survival (\%) } \\
\cline { 2 - 5 } & Day 7 & Day 10 & Day 14 & Day 21 \\
\hline Antitranspirant treatment & \multicolumn{5}{c}{ Repeat $\mathbf{1}$} \\
Stomata-closing & 100 & 97 & $97 \mathrm{a}^{\mathrm{z}}$ & $97 \mathrm{a}$ \\
Stomata-coating & 97 & 89 & $53 \mathrm{c}$ & $50 \mathrm{c}$ \\
Stomata-coating + stomata-closing & 100 & 100 & $100 \mathrm{a}$ & $100 \mathrm{a}$ \\
Water (control) & 97 & 97 & $75 \mathrm{~b}$ & $72 \mathrm{~b}$ \\
Pvalue & 0.59 & 0.11 & $<0.0001$ & $<0.0001$ \\
& \multicolumn{4}{c}{ Repeat 2} \\
Stomata-closing & $97 \mathrm{a}$ & $97 \mathrm{a}$ & $87 \mathrm{ab}$ & $79 \mathrm{~b}$ \\
Stomata-coating & $87 \mathrm{~b}$ & $83 \mathrm{~b}$ & $72 \mathrm{c}$ & $60 \mathrm{c}$ \\
Stomata-coating + stomata-closing & $100 \mathrm{a}$ & $99 \mathrm{a}$ & $96 \mathrm{a}$ & $92 \mathrm{a}$ \\
Water (control) & $97 \mathrm{a}$ & $96 \mathrm{a}$ & $83 \mathrm{bc}$ & $72 \mathrm{~b}$ \\
Pvalue & 0.001 & 0.0008 & 0.008 & $<0.0001$ \\
\hline
\end{tabular}

${ }^{\mathrm{z}}$ Mean separation letters generated using least square means statement in JMP (version 11.0 for Windows; SAS Institute) at $\alpha=0.05$. Values in columns followed by the same letter are not significantly different.

Table 2. Survival of 'TriX Palomar' watermelon grafted onto 'Emphasis' rootstock treated $1 \mathrm{~d}$ before grafting with a stomata-closing antitranspirant, a stomata-coating antitranspirant, stomata-coating + stomata-closing antitranspirants, or water; survival was measured at $7,10,14$, and $21 \mathrm{~d}$ after grafting, which was 29 Jan. 2016 (repeat 1) and 5 Feb. 2016 (repeat 2) at Mount Vernon, WA.

\begin{tabular}{lcccc}
\hline & \multicolumn{4}{c}{ Survival (\%) } \\
\cline { 2 - 5 } & Day 7 & Day 10 & Day 14 & Day 21 \\
\hline Antitranspirant treatment & \multicolumn{4}{c}{ Repeat 1 } \\
Stomata-closing & 100 & $92 \mathrm{a}^{\mathbf{z}}$ & $89 \mathrm{a}$ & $87 \mathrm{a}$ \\
Stomata-coating & 95 & $72 \mathrm{~b}$ & $53 \mathrm{~b}$ & $50 \mathrm{~b}$ \\
Stomata-coating + stomata-closing & 100 & $95 \mathrm{a}$ & $84 \mathrm{a}$ & $84 \mathrm{a}$ \\
Water (control) & 91 & $89 \mathrm{a}$ & $67 \mathrm{~b}$ & $53 \mathrm{~b}$ \\
Pvalue & 0.22 & 0.03 & 0.003 & 0.0004 \\
& & \multicolumn{2}{c}{ Repeat 2 } & \\
Stomata-closing & $100 \mathrm{a}$ & $100 \mathrm{a}$ & $97 \mathrm{a}$ & $97 \mathrm{a}$ \\
Stomata-coating & $98 \mathrm{a}$ & $88 \mathrm{~b}$ & $73 \mathrm{~b}$ & $66 \mathrm{~b}$ \\
Stomata-coating + stomata-closing & $100 \mathrm{a}$ & $94 \mathrm{ab}$ & $94 \mathrm{a}$ & $94 \mathrm{a}$ \\
Water (control) & $91 \mathrm{~b}$ & $78 \mathrm{c}$ & $70 \mathrm{~b}$ & $68 \mathrm{~b}$ \\
Pvalue & 0.03 & $<0.0001$ & $<0.0001$ & 0.0001 \\
\hline
\end{tabular}

${ }^{\mathrm{z}}$ Mean separation letters generated using least square means statement in JMP (version 11.0 for Windows; SAS Institute) at $\alpha=0.05$. Values in columns followed by the same letter are not significantly different. 
Table 3. Mean stomatal conductance $\left(g_{s}\right)$ for 'TriX Palomar' watermelon and 'Emphasis' rootstock seedlings (plants were not grafted) just before antitranspirant treatment application (day 0 ) and 1 and $2 \mathrm{~d}$ after application, on 4, 5, and 6 Feb. 2016, respectively, at Mount Vernon, WA.

\begin{tabular}{lccc}
\hline & \multicolumn{3}{c}{ Watermelon seedling $\mathscr{g}_{\mathrm{s}}\left(\mathbf{m m o l} \cdot \mathbf{m}^{-2} \cdot \mathbf{s}^{-\mathbf{l}}\right)$} \\
\hline Antitranspirant treatment & Day $\mathbf{0}$ & Day $\mathbf{~}$ & Day 2 \\
Stomata-closing & 391 & $170 \mathrm{~b}^{\mathrm{z}}$ & $147 \mathrm{~b}$ \\
Stomata-coating & 260 & $223 \mathrm{~b}$ & $187 \mathrm{~b}$ \\
Stomata-coating + stomata-closing & 225 & $89 \mathrm{c}$ & $118 \mathrm{~b}$ \\
Water (control) & 288 & $320 \mathrm{a}$ & $264 \mathrm{a}$ \\
$P$ value & 0.33 & 0.0002 & 0.006 \\
& Rootstock seedling $g_{\mathrm{s}}\left(\mathbf{m m o l} \cdot \mathbf{m}^{-2} \cdot \mathbf{s}^{-\mathbf{1}}\right)$ \\
Stomata-closing & 385 & $163 \mathrm{~b}$ & $122 \mathrm{c}$ \\
Stomata-coating & 280 & $262 \mathrm{a}$ & $221 \mathrm{c}$ \\
Stomata-coating + stomata-closing & 257 & $142 \mathrm{~b}$ & $150 \mathrm{~b}$ \\
Water (control) & 264 & $311 \mathrm{a}$ & $361 \mathrm{a}$ \\
$P$ value & 0.23 & $<0.0001$ & $<0.0001$ \\
\hline
\end{tabular}

${ }^{\mathrm{z}}$ Mean separation letters generated using least square means statement in JMP (version 11.0 for Windows; SAS Institute) at $\alpha=0.05$. Values in columns followed by the same letter are not significantly different.

Table 4. Contrast of stomatal conductance ( $\left.g_{s}\right)$ for 'TriX Palomar' watermelon and 'Emphasis' rootstock seedlings (plants were not grafted) before (day 0 ) and 1 and 2 d after antitranspirant treatment application, on 4, 5, and 6 Feb. 2016, respectively, at Mount Vernon, WA.

\begin{tabular}{lcc}
\hline & Contrast $(P)$ of $g_{s}$ for watermelon seedlings $\mathbf{z}^{\mathrm{z}}$ \\
\hline Antitranspirant treatment & Day 0 vs. day $\mathbf{~}$ & Day 0 vs. day 2 \\
Stomata-closing & 0.0008 & 0.0003 \\
Stomata-coating & 0.54 & 0.22 \\
Stomata-coating + stomata-closing & 0.03 & 0.08 \\
Water (control) & 0.61 & 0.68 \\
& Contrast $(P)$ of $g$ s for rootstock seedlings \\
Stomata-closing & $<0.0001$ & $<0.0001$ \\
Stomata-coating & 0.68 & 0.18 \\
Stomata-coating + stomata-closing & 0.01 & 0.02 \\
Water (control) & 0.29 & 0.03 \\
\hline
\end{tabular}

${ }^{\mathrm{z}}$ Mean contrast using least square means statement in JMP (version 11.0 for Windows; SAS Institute) at $\alpha=0.05$.

seedlings. Stomatal conductance was measured for the most recent fully expanded leaf of each 'TriX Palomar' seedling and one cotyledon of each 'Emphasis' seedling.

Data Analysis. Data were subjected to analysis of variance using JMP software (version 11.0 for Windows; SAS Institute, Cary, NC). Antitranspirant treatments and water treatments were explanatory variables, and grafting survival and $g_{s}$ were response variables. The survival of grafted transplants for Expts. 1 and 2 were transformed using the arcsine of the square root. Least square means was used to run a customized F-test to contrast difference in level of $g_{s}$ for different treatments before and 1 and $2 \mathrm{~d}$ after treatment application. Microsoft Excel (Microsoft Office 2013 for Windows; Microsoft, Redmond, WA) was used to calculate daily averages of measured environmental factors.

\section{Results}

Grafted plant survival. The survival (percent) of grafted watermelon differed because of experiment $(P=0.005)$, and in each experiment there was a difference due to repeat $(P<0.0001)$, treatments $(P<0.0001)$, and days after grafting $(P<0.0001)$. The survival of grafted plants was near $100 \%$ for all four treatments $7 \mathrm{~d}$ after grafting. At $10 \mathrm{~d}, 1 \mathrm{~d}$ after plants were removed from the chamber and placed on the greenhouse bench, plant survival began to decline for most treatments, and survival declined even further by $21 \mathrm{~d}$ after grafting for the stomata-coating antitranspirant and water treatments. In repeat 1 of Expt. 1, where 'Tetsukabuto' was the rootstock, there was no significant difference in survival because of treatments at $7 \mathrm{~d}$ (average $99 \%$ ) or $10 \mathrm{~d}$ (average 96\%) after grafting (Table 1). At $14 \mathrm{~d}$ after grafting, survival of plants treated with the stomatacoating antitranspirant was $53 \%$ and survival of plants treated with water was $75 \%$, whereas survival of plants treated with the stomata-closing antitranspirant or stomata-coating + stomata-closing antitranspirants were $100 \%$ and 97\%, respectively. By $21 \mathrm{~d}$ after grafting, plants treated with the stomata-coating antitranspirant or water decreased to $50 \%$ and $72 \%$, respectively, whereas survival of plants treated with the stomata-closing antitranspirant or stomata-coating + stomata-closing antitranspirants did not change. In repeat 2 , survival differed because of treatment by $7 \mathrm{~d}$, with plants treated with the stomatacoating antitranspirant showing the lowest survival $(87 \%)$, and survival of plants with the other three treatments averaged 98\% (Table 1). At $10 \mathrm{~d}$ after grafting, survival of plants treated with the stomata-coating antitranspirant had the lowest survival $(83 \%)$, whereas survival of plants with other treatments averaged 97\%. By $14 \mathrm{~d}$ after grafting, plants treated with the stomata-coating + stomata-closing antitranspirants $(96 \%)$ or the stomataclosing antitranspirant (87\%) had higher survival than plants treated with the stomata-coating antitranspirant $(72 \%)$ or water $(83 \%)$. By $21 \mathrm{~d}$ after grafting, plants treated with the stomata-coating + stomata-closing antitranspirants continued to have the highest survival (92\%), plants treated with the stomata-closing antitranspirant or water had intermediate survival (average 76\%), and survival of plants treated with the stomata-coating antitranspirant was reduced to $60 \%$.

In Expt. 2, where the rootstock was 'Emphasis', all plants in the first repeat were affected by powdery mildew (Erysiphe polygoni). Despite this, a fungicide was not applied as it could have affected seedling $\mathscr{y}_{S}$, and the disease likely caused a lower overall plant survival in repeat $1(70 \%)$ as compared with repeat $2(81 \%)$. In repeat 1 , there was no significant difference in survival because of treatments at $7 \mathrm{~d}$ after grafting (97\% on average) (Table 2). By $10 \mathrm{~d}$ after grafting, survival of plants treated with the stomata-coating 
antitranspirant dropped to $72 \%$, whereas survival of plants treated with the other three treatments averaged $92 \%$. At 14 and $21 \mathrm{~d}$ after grafting, survival was highest for plants treated with the stomata-closing antitranspirant (average $88 \%$ ) followed by the stomata-coating + stomata-closing antitranspirants (84\%), and was lowest for the stomata-coating antitranspirant (average 52\%). In repeat 2, differences due to treatments began $7 \mathrm{~d}$ after grafting and followed the same trend as repeat 1 (Table 2). Plants treated with water $(91 \%)$ had a lower survival on day 7 than plants treated with the other three treatments (average 99\%). At $10 \mathrm{~d}$ after grafting, survival of plants treated with the stomata-closing antitranspirant or the stomata-coating + stomataclosing antitranspirants averaged $97 \%$, the stomata-coating antitranspirant was intermediate $(88 \%)$, and water was low (78\%). By $14 \mathrm{~d}$ after grafting, plants treated with the stomata-closing antitranspirant or the stomata-coating + stomata-closing antitranspirants (average 96\%) had higher survival than plants treated with the stomata-coating antitranspirant or water (average $72 \%$ ). By $21 \mathrm{~d}$ after grafting there was no further loss for plants treated with the stomata-closing antitranspirant or the stomata-coating + stomata-closing antitranspirants compared with day 14, whereas survival declined for plants treated with the stomata-coating antitranspirant or water (average 67\%).

Stomatal conductance. In Expt. 3, gs was similar for 'TriX Palomar' seedlings $\left(29 \mathrm{l} \mathrm{mmol} \cdot \mathrm{m}^{2} \cdot \mathrm{s}^{1}\right)$ and for 'Emphasis' seedlings $\left(297 \mathrm{mmol} \cdot \mathrm{m}^{2} \cdot \mathrm{s}^{1}\right)$ before treatment application (day 0 ) and differed because of treatment at 1 and $2 \mathrm{~d}$ after application (Table 3). Stomatal conductance of 'TriX Palomar' and 'Emphasis' seedlings treated with the stomata-coating antitranspirant did not change 1 or $2 \mathrm{~d}$ after application (Tables 3 and 4). Stomatal conductance of 'TriX Palomar' seedlings treated with water did not change 1 or $2 \mathrm{~d}$ after application; however, $g_{S}$ of 'Emphasis' seedlings increased 37\% on day 2 after water application. Stomatal conductance of 'TriX Palomar' and 'Emphasis' seedlings treated with the stomata-closing antitranspirant decreased $58 \%$ at $1 \mathrm{~d}$ and $65 \%$ on average at $2 \mathrm{~d}$ after application.
Stomatal conductance of 'TriX Palomar' and 'Emphasis' seedlings treated with the stomata-coating + stomataclosing antitranspirants decreased $53 \%$ and $45 \%$ on average at 1 and 2 $\mathrm{d}$ after application, respectively ( $\mathrm{Ta}-$ bles 3 and 4 ).

ENVIRONMENTAL CONDITIONS. Daily average temperature and $\mathrm{RH}$ in the healing chamber and in the greenhouse were similar for both repeats of Expts. 1 and 2 (Figs. 1 and 2 ); however, light intensity (measured only in Expt. 2) differed for each repeat after the fabric was removed from the chamber (Fig. 3). Daily average temperature inside the chamber was $24-27^{\circ} \mathrm{C}$, whereas the daily average temperature in the greenhouse was $22-27^{\circ} \mathrm{C}$. In the first $3 \mathrm{~d}$ after grafting, when the plastic of the chamber was closed and the chamber was entirely covered with black fabric, the daily average temperature inside the chamber was the same as the temperature inside the greenhouse, $24-27^{\circ} \mathrm{C}$. Daily average $\mathrm{RH}$ during this time was $94 \%$ to $98 \%$ inside the chamber and $32 \%$ to $41 \%$ in the greenhouse, and the daily average light intensity in the chamber was 60$74 \mathrm{~lx}$. From day 4 to day 6 , when plants in the chamber were exposed to the greenhouse environment for $\mathrm{l} \mathrm{h}$ or less each day, and the chamber was partially covered with black fabric, daily average temperature inside the chamber was $24-27^{\circ} \mathrm{C}$ and temperature in the greenhouse was $25-$ $27^{\circ} \mathrm{C}$. Daily average RH during this time was $96 \%$ to $98 \%$ inside the chamber and $25 \%$ to $42 \%$ in the greenhouse, whereas the daily average light intensity in the chamber was $333-453$ lx. For 7-9 d after grafting, when plants in the chamber were exposed $5 \mathrm{~h}$ on average each day to the greenhouse environment and the

Expt. 1

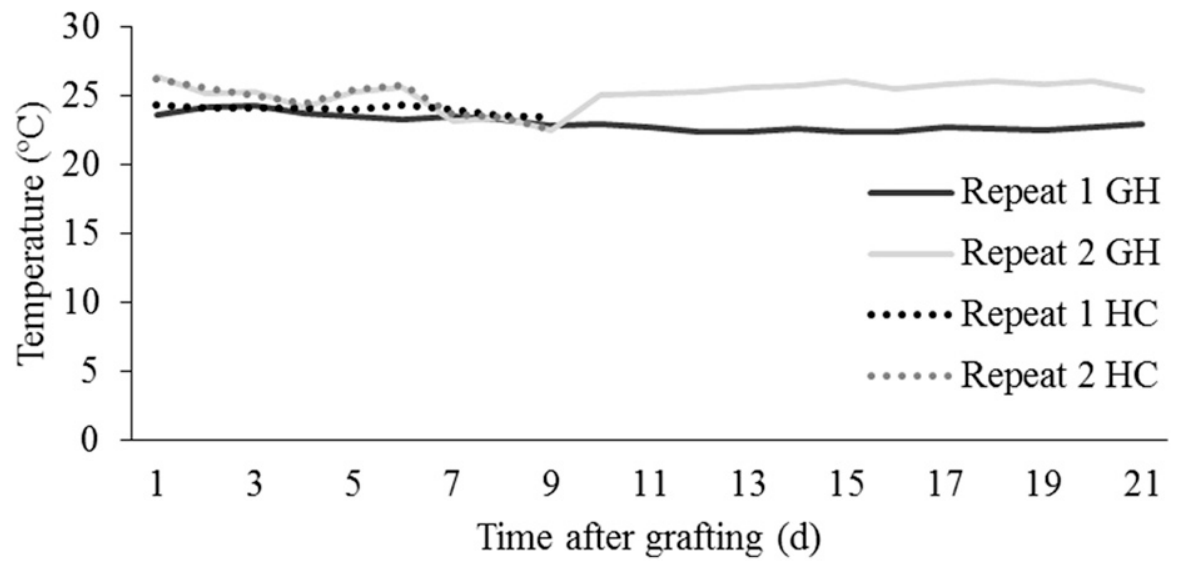

Expt. 2

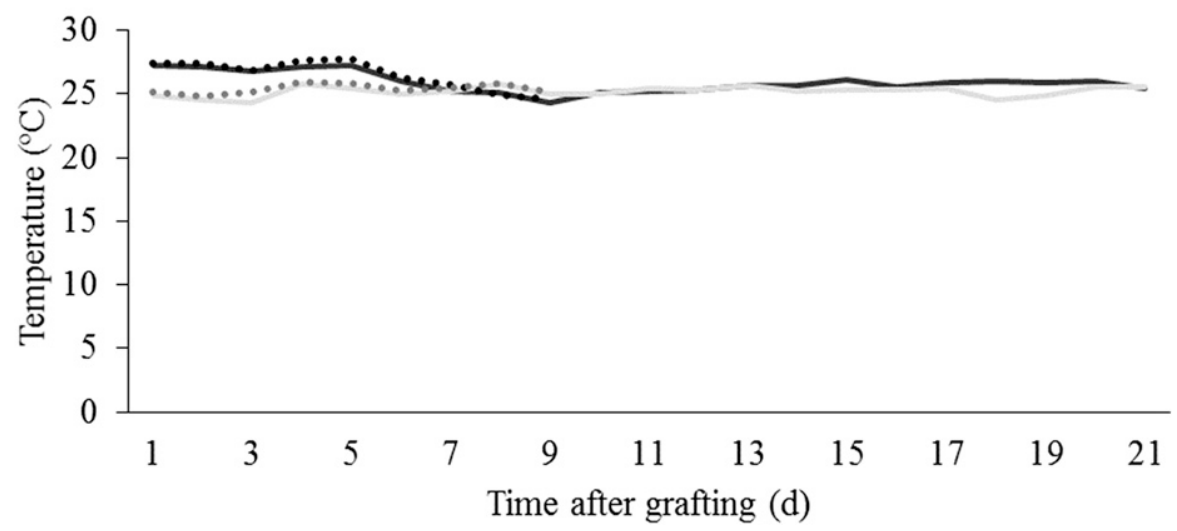

Fig. 1. Temperature in the healing chamber (HC) and greenhouse (GH) for $21 \mathrm{~d}$ after grafting 'TriX Palomar' watermelon onto 'Tetsukabuto' rootstock in Expt. 1 (repeat 1 was $3 \mathrm{Feb}$. to $24 \mathrm{Feb}$. 2015; repeat 2 was 12 Mar. to $2 \mathrm{Apr}$. 2015), and onto 'Emphasis' rootstock in Expt. 2 (repeat 1 was 29 Jan. to 19 Feb. 2016; repeat 2 was 5 Feb. to $26 \mathrm{Feb} .2016)$, at Mount Vernon, WA; $\left(1.8 \times{ }^{\circ} \mathrm{C}\right)+32={ }^{\circ} \mathrm{F}$. 
Expt. 1

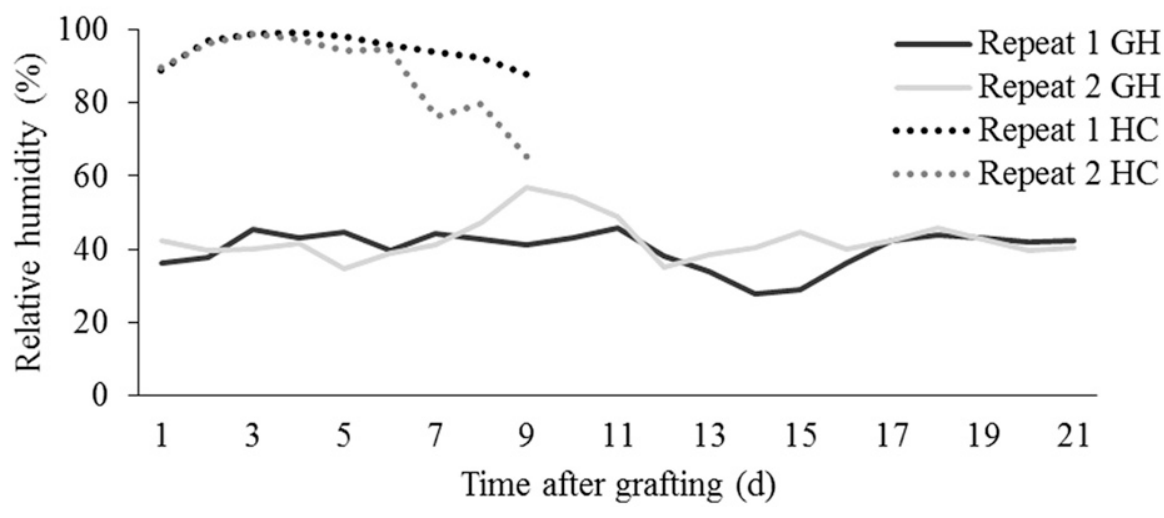

Expt. 2

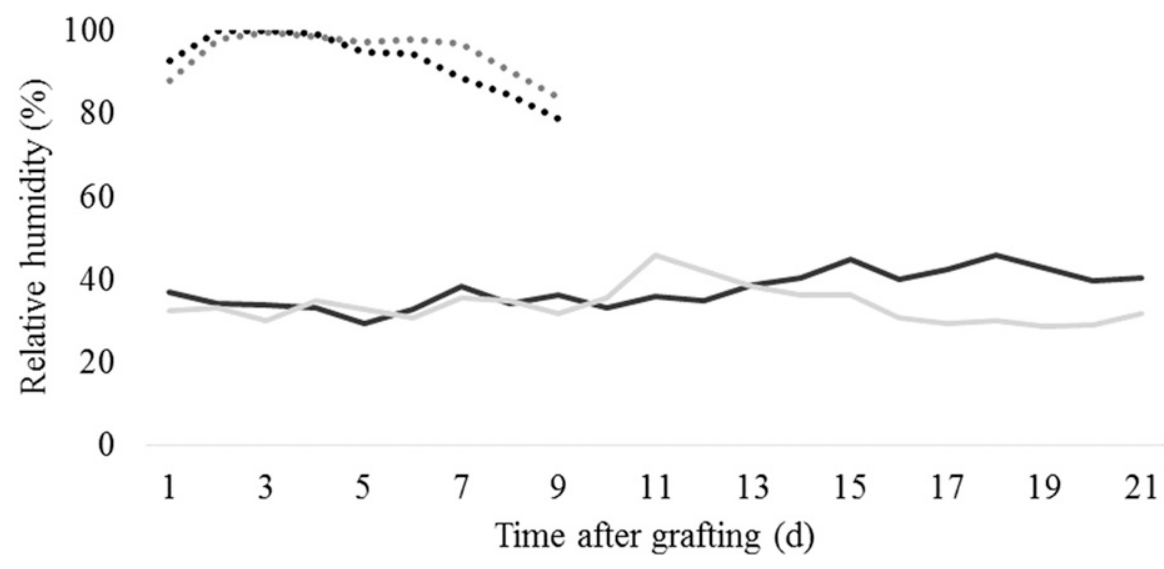

Fig. 2. Relative humidity in healing chamber (HC) or greenhouse (GH) for $21 \mathrm{~d}$ after grafting 'TriX Palomar' watermelon onto 'Tetsukabuto' rootstock in Expt. 1 (repeat 1 was $3 \mathrm{Feb}$. to $24 \mathrm{Feb}$. 2015; repeat 2 was 12 Mar. to 2 Apr. 2015), and onto 'Emphasis' rootstock in Expt. 2 (repeat 1 was 29 Jan. to 19 Feb. 2016; repeat 2 was 5 Feb. to 26 Feb. 2016), at Mount Vernon, WA.

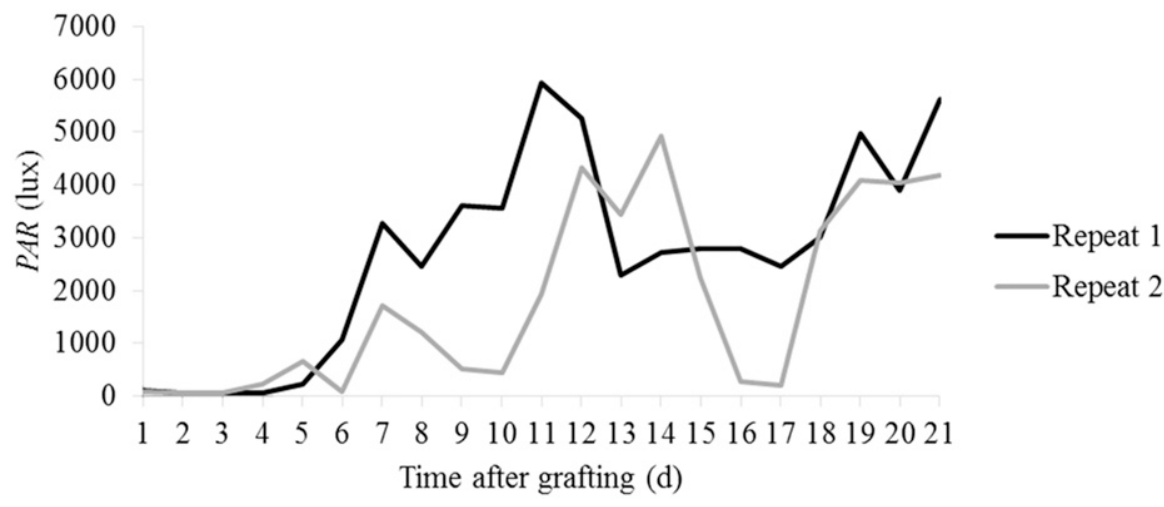

Fig. 3. Intensity of photosynthetically active radiation (PAR) in the healing chamber for $21 \mathrm{~d}$ after grafting 'TriX Palomar' watermelon seedlings onto 'Emphasis' rootstock (Expt. 2 repeat 1 was 29 Jan. to 19 Feb. 2016; repeat 2 was $5 \mathrm{Feb}$. to $26 \mathrm{Feb}$. 2016) at Mount Vernon, WA; $1 \mathrm{~lx}=0.09 \mathrm{fc}$.

black fabric was removed, the temperature inside the chamber and the temperature in the greenhouse were $23-25{ }^{\circ} \mathrm{C}$. Daily average RH during this time was $78 \%$ to $98 \%$ inside the chamber and $34 \%$ to $48 \%$ in the greenhouse. The daily average light intensity in the chamber during this period varied for each repeat, and was $3095 \mathrm{~lx}$ in repeat $\mathrm{l}$ and $1155 \mathrm{~lx}$ in repeat 2. After day 9, when plants were removed from the chamber, the daily average temperature in the greenhouse was $23-25{ }^{\circ} \mathrm{C}$ and the RH was $40 \%$ to $47 \%$. The daily average light intensity in the greenhouse differed for each repeat, and was 3788 $\mathrm{lx}$ in repeat $\mathrm{l}$ and $1617 \mathrm{~lx}$ in repeat 2.

\section{Discussion}

The stomata-closing antitranspirant applied to 'TriX Palomar', 'Tetsukabuto', and 'Emphasis' seedlings $\mathrm{l} \mathrm{d}$ before grafting resulted in $90 \%$ graft survival, on average, $21 \mathrm{~d}$ after grafting, and this was a $25 \%$ increase in survival compared with water-treated plants. By contrast, the stomata-coating antitranspirant, which physically blocks stomatal openings, resulted in graft survival of $57 \%$ on average. The stomata-closing antitranspirant caused a decrease in $g_{s}$ of both 'TriX Palomar' and 'Emphasis' seedlings in this study, whereas $g$ s after the stomata-coating antitranspirant application was not reduced compared with the preapplication level. These results suggest that greater graft survival occurred because of the reduction in $g_{S}$ and the likely concurrent reduction in transpiration. In other studies, antitranspirants were applied after grafting (Iriti et al., 2009; Joy, 2010). Applying antitranspirant products before grafting appears to better prepare seedlings for the stress of grafting and healing, leading to greater graft survival.

Mean survival $21 \mathrm{~d}$ after grafting of 'TriX Palomar' grafted on 'Tetsukabuto' was $72 \%$, and was $61 \%$ for 'Emphasis' rootstock. This result suggests that rootstocks may influence grafting success in small-scale grafting operations where environmental conditions are not well controlled. Rootstocks should be evaluated further to determine their suitability for smallscale grafting operations. To further understand the effect of antitranspirant products on grafted seedling health and vigor, plant growth and development should also be measured. Also needed is the evaluation of more antitranspirant products that are allowed for use on vegetable transplants. Most products are only allowed on ornamental or nonedible plants, and in the time from initiation to publication of this study, the stomataclosing antitranspirant included in this 
study is no longer available. To address this need, products such as chitosan should be evaluated. Chitosan is a naturally derived antitranspirant that has been shown to elicit plant defense mechanisms resulting in stomatal closure and reduction in transpiration (Bittelli et al., 2001; Iriti et al., 2009; Park et al., 2016). Joy (2010) observed that when chitosan was applied as a foliar antitranspirant to self-grafted 'Cherokee Purple' tomato under two RH treatments (37\% and $95 \%$ ), chitosan-treated plants had 30\% higher survival than nontreated plants at both levels of $\mathrm{RH}$ on day 10 (when plants were fully acclimated). In the same study, there was no significant difference in survival between chitosan-treated and nontreated self-grafted 'Maxifort' tomato rootstock plants, indicating the benefit could be cultivar specific, further suggesting a need to test different rootstocks. To fill this information gap, new studies are underway at WSU NWREC to test the effect of a commercial chitosan product on the grafting survival of watermelon.

An additional limitation to the current study procedures is the use of the leaf porometer, which must occur between 11:30 AM and 1:30 PM so as to measure the maximum $g_{s}$ (Pietragalla and Pask, 2012). The current study included the maximum number of plants that could be measured within this time frame in the greenhouse environment at this location. It took $\approx 10$ min to calibrate the instrument at the beginning of each measurement day, and 1-2 min to collect each measurement plus $30 \mathrm{~s}$ to recalibrate between each measurement. Another limitation is that gs cannot be measured on grafted seedlings the first $4 \mathrm{~d}$ after grafting as during this period grafted plants are in the dark and $g_{S}$ is measured in the light. If grafted plants are removed from the chamber for the measurement, this would disrupt the healing process and likely kill the transplant. After $3 \mathrm{~d}$, when plants can be exposed to the light and greenhouse environment for a limited time (10-30 $\min$ ), $g_{s}$ could be measured on a small number of plants. However, the high $\mathrm{RH}$ in the chamber can prevent accurate measurement with the leaf porometer. Measuring $g_{S}$ on newly grafted watermelon plants is logistically challenging and needs to be further explored.

\section{Literature cited}

Atkinson, C.J. and M.A. Else. 2001. Understanding how rootstocks dwarf fruit trees. Compact Fruit Tree 34 (2):46-49.

Bittelli, M., M. Flury, G.S. Campbell, and E.J. Nichols. 2001. Reduction of transpiration through foliar application of chitosan. Agr. For. Meteorol. 104:167-175.

Boughalleb, N., N. Tarchoun, A. El Mbarki, and M. El Mahjoub. 2007. Resistance evaluation of nine cucurbit rootstocks and grafted watermelon (Citrullus lanatus L.) varieties against fusarium wilt and fusarium crown rot. J. Plant Sci. 2(1): 102-107.

Buller, S., D. Inglis, and C. Miles. 2013. Plant growth, fruit yield and quality, and tolerance to verticillium wilt of grafted watermelon and tomato in filed production in the Pacific Northwest. HortScience 48:1003-1009.

Cohen, R., Y. Burger, and C. Horev. 2007. Introducing grafted cucurbits to modern agriculture: The Israeli experience. Plant Dis. 91:916-923.

Dabirian, S., D. Inglis, and C. Miles. 2017. Grafting watermelon and using plastic mulch to control verticillium wilt caused by Verticillium dabliae in Washington. HortScience 52:349-356.

Davis, A.R., P. Perkins-Veazie, Y. Sakata, S. Lopez-Galarza, J.V. Marot, S. Lee, Y. Huh, Z. Sun, A. Miguel, S.R. King, R. Cohen, and J. Lee. 2008. Cucurbit grafting. Crit. Rev. Plant Sci. 27:50-74.

Davies, W.J. and J. Zhang. 1991. Root signals and the regulation of growth and development of plants in drying soil. Annu. Rev. Plant Physiol. Plant Mol. Biol. 42:55-76.

Galinato, S.P., C.A. Miles, and J.A Wimer. 2016. Non-grafted and grafted seedless watermelon transplants: Comparative economic feasibility analysis. Washington State Univ. Ext. Bul. TB08.

Gomez-Cadenas, A., V. Arbona, J. Jacas, E. Primo-Millo, and M. Talon. 2003. Abscisic acid reduces leaf abscission and increases salt tolerance in citrus plants. J. Plant Growth Regul. 21:234-240.

Grill, E. and H. Ziegler. 1998. A plants dilemma. Science 282:252-253.

Guan, W., X. Zhao, R. Hassell, and J. Thies. 2012. Defense mechanisms involved in disease resistance of grafted vegetable. HortScience 47:164-170.

Hetherington, A. and W.J. Davis. 1998. Special issue: Stomatal biology. J. Expt. Bot. 49:293-469.
Iriti, M., V. Picchi, M. Rossoni, St. Gomarasca, N. Ludwig, M. Gargano, and F. Faoro. 2009. Chitosan antitranspirant activity is due to abscisic acid-dependent stomatal closure. Environ. Expt. Bot. 66:493-500.

Johkan, M., M. Oda, and G. Mori. 2008. Ascorbic acid promotes graft-take in sweet pepper plants (Capsicum annuum L.). Sci. Hort. 116:343-347.

Johkan, M., K. Mitukuri, S. Yamasaki, G. Mori, and M. Oda. 2009. Causes of defoliation and low survival rate of grafted sweet pepper plants. Sci. Hort. 119:103107.

Johnson, S.J. and C.A. Miles. 2011. Effect of healing chamber design on the survival of grafted eggplant, tomato, and watermelon. HortTechnology 21:752758 .

Joy, S. 2010. Effect of foliar application of chitosan on stomatal conductance and survival of grafted transplants. 25 May 2017. <http://veggiegraft.blogspot. com $/ 2010 / 04 />$.

Khalil, A.A.M. and J. Grace. 1993. Does xylem sap ABA control the stomatal behavior of water-stressed sycamore (Acer pseudoplatanaus L.) seedlings? J. Expt. Bot. 44:1127-1134.

Lee, S.H., G.C. Chung, and E. Steudle. 2005. Low temperature and mechanical stresses differently gate aquaporins of root cortical cells of chilling-sensitive cucumber and resistant figleaf gourd. Plant Cell Environ. 28:1191-1202.

Leung, J. and J. Giraudat. 1998. Abscisic acid and signal transduction. Annu. Rev. Plant Physiol. Plant Mol. Biol. 49:199222.

Lewis, M., C. Kubota, R. Tronstad, and Y.-J. Son. 2014. Scenario-based cost analysis for vegetable grafting nurseries of different technologies and sizes. HortScience 49:917-930.

Louws, F.J., C.L. Rivard, and C. Kubota. 2010. Grafting fruiting vegetables to manage soilborne pathogens, foliar pathogens, arthropods and weeds. Sci. Hort. 127:127-146.

Miles, C., L. Hesnault, S. Johnson, P. Kreider, and S. Dabirian. 2016. Vegetable grafting: Watermelon. Washington State Univ. Ext. Publ. FS100E.

Moftah, A.E. and K.N. Al-Redhaiman. 2006. Effect of preharvest foliar spray of 'Limewash' on water relations, quantity, quality, and shelf life of bell pepper under water deficit conditions. Eur. J. Hort. Sci. 71:78-83.

Nitzsche, P., G.A. Berkowitz, and J. Rabin. 1991. Development of a seedling- 
applied antitranspirant formulation to enhance water status, growth, and yield of transplanted bell pepper. J. Amer. Soc. Hort. Sci. 116:405-411.

Oda, M., M. Maruyama, and G. Mori. 2005. Water transfer at graft union of tomato plants grafted onto Solanum rootstocks. J. Jpn. Soc. Hort. Sci. 74:458463.

Park, S., S.A. Mills, Y. Moon, and N.L. Waterland. 2016. Evaluation of antitranspirant for enhancing temporary water stress tolerance in bedding plants. HortTechnology 26:444-452.

Pietragalla, J. and A. Pask. 2012. Stomatal conductance, p. 15-17. In: A.J.D. Pask, J. Pietragalla, D.M. Mullan, and M.P. Reynolds (eds.). Physiological breeding II: A field guide to wheat phenotyping. CIMMYT, Mexico, D.F.

Pospisilova, J. 2003. Participation of phytohormones in the stomatal regulation of gas exchange during water stress. Biol. Plant. 46:491-506.
Rivard, C. and F.J. Louws. 2006. Grafting for disease resistance in heirloom tomatoes. North Carolina State Univ. Coop. Ext. Serv. Bul. 675.

Rivard, C.L., O. Sydorovych, S. O'Connell, M.M. Peet, and F.J. Louws. 2010. An economic analysis of two grafted tomato transplant production systems in the United States. HortTechnology 20:794803.

Shirai, T. and M. Hagimori. 2004. Studies in establishment of transplant production methods of sweet pepper (Capsicum annuum L.) by grafting shoots harvested from mother plants: Effect of healing conditions of grafts on the rate and quality of successful union. J. Jpn. Soc. Hort. Sci. 73:380-385.

Tambussi, E.A. and J. Bort. 2007. Water use efficiency in C3 cereals under Mediterranean conditions: A review of physiological aspects. Ann. Appl. Biol. 150:307-321.
Willmer, C.M. and M. Pricker. 1996. Stomata. 2nd ed. Chapman Hall, London, UK.

Wimer, J.A., C.A. Miles, and D.A. Inglis. 2015. Evaluating grafted watermelon for ferticillium wilt severity, yield, and fruit quality in Washington State. HortScience 50:1332-1337.

Zhang, J. and W.J. Davies. 1990. Changes in the concentration of ABA in xylem sap as a function of changing soil water status can account for changes in leaf conductance and growth. Plant Cell Environ. 13:277285. 